\title{
An immunohistochemical study of endocrine cells in the pancreas of the Red-bellied frog (Bombina orientalis)
}

\author{
J-h. Lee, S-k. Ku, ${ }^{*}$ H-s. Lee, ${ }^{\circ}$ H. Kitagawa ${ }^{\S}$ \\ Department of Histology, College of Veterinary Medicine, Kyungpook National University; *Pharmacology \\ \& Toxicology Laboratory, Central Research Laboratories, Dong-Wha Pharm. Ind. Co.; 'Department of \\ Biology, Faculty of Natural Sciences, Kyungsan University; '\$Department of Life Science, Graduate School \\ of Science and Technology, Kobe University, Japan
}

CC2003, European Journal of Histochemistry

The regional distribution and frequency of pancreatic endocrine cells in the red-bellied frog, Bombina orientalis, were studied by the immunohistochemical peroxidase antiperoxidase (PAP) method using five types of specific mammalian antisera to insulin, glucagon, somatostatin, bovine pancreatic polypeptide (PP) and secretin. The frequency was calculated as the mean number of each endocrine cell type/1,000 total cells (including exocrine and endocrine cells) using an automated image analysis process. The percentage of each immunoreactive (IR) cell species to the total IR cell population was also calculated. In the pancreas of the red-bellied frog, all five endocrine cell types were demonstrated. Insulin IR cells were located in the pancreas as single cells or islet-like clusters. The latter were localized in central regions. The insulin-IR cells showed a frequency of $65.40 \pm 14.56 / 1,000$ cells. Glucagon IR cells were also detected as single cells or as clusters but in the case of clusters, two distributional patterns were detected - a central core type and a marginally distributed type. They showed an abundance of $32.70 \pm 7.32 / 1,000$ cells. Somatostatin-IR cells were dispersed throughout the pancreatic parenchyma as single cells, three to four cells, or clusters. The clusters were located in the marginal regions. The somatostatin-IR cell frequency was $19.40 \pm 6.52 / 1000$ cells. PP-IR cells were randomly distributed throughout the pancreatic parenchyma as single cells with a frequency of $14.70 \pm 4.92 / 1,000$ cells. Secretin-IR cells were demonstrated as clusters or as single cells, and as clusters they occupied the central regions. They showed a frequency of $39.60 \pm 10.36 / 1,000$ cells. This is the first report of the presence of secretin-IR cells in amphibian pancreatic endocrine cells. Overall, there were $37.20 \pm 6.84 \%$ insulin-, $21.90 \pm 5.55 \%$ glucagon-, $11.60 \pm 4.33 \%$ somatostatin-, $8.60 \pm 2.72 \%$ PP- and $23.40 \pm 4.45 \%$ secretin-IR cells.

Key words: Red-bellied frog, Bombina orientalis, pancreas, endocrine cells, immunohistochemistry.

Correspondence: Dr. Hyeung-sik Lee, Department of Biology, Faculty of Natural Sciences, Kyungsan University, Kyungsan, Kyungpook, 712-240, Republic of Korea. Phone: international +82-53-819-1436. Fax: international +82-53-8191558. E-mail: endohist@kyungsan.ac.kr

Paper accepted on February 27, 2003.

European Journal of Histochemistry 2003; vol. 47 issue 2 [Apr-Jun]:165-172
7 here has been a surge of interest in the endocrine cells of the gastroenteropancreatic (GEP) system of amphibia in recent years. This is not remarkable considering that so many GEP neuropeptides have been isolated from the amphibian skin (Nakajima et al., 1979; Van Noorden and Polak, 1979). The pancreas is well accepted as a valuable organ for endocrine studies, particularly because of the association of this organ with diabetes (Jansson and Sandler, 1988). In addition, the investigations of GEP endocrine cells have been considered as an important part of phylogenetic studies (D’Este et al., 1994).

It is generally known that the pancreas of vertebrates is divided into two portions, i.e. the exocrine portion, from which digestive enzymes are released, and the endocrine portion, from which regulatory hormones, such as insulin, glucagon, somatostatin and pancreatic polypeptide $(P P)$, are released into the blood circulation. The appearance, regional distribution and relative frequency of these regulatory hormones secreted by the endocrine cells in the pancreas have been carefully elucidated by histochemistry (Kobayashi and Syed Ali, 1981), immunofluorescence (Orci, 1982) and immunohistochemistry (Sternberger et al., 1970). In addition to the above regulatory hormones, peptide $Y Y$-, neuropeptide $Y Y$ (Ali-Rachedi et al., 1984), motilin- (Yamada et al., 1986) and chromogranin family- (Rindi et al., 1986; Ito et al., 1987) immunoreactive (IR) cells were also demonstrated in the vertebrate pancreas.

The regional distribution and relative frequency of insulin, glucagon, somatostatin and PP have also been reported in the pancreas of some anurans such as the European common frog (Rana temporaria) (Etayo et al., 2000), the green frog (Rana esculenta) (Trandaburu et al., 1995), the African clawed toad (Xenopus laevis) (Hacker et al., 1983; Shapiro et al., 1979; Cowan et al., 1991), the Japanese newt (Cynopus pyrrhogaster) (Oikawa et al., 1992) and the newt (Notophthalmus viridescens) (Foty et al., 
1989). In addition, adrenomedullin- (Lopez et al., 1999), peptide tyrosine tyrosine- (Lozano et al., 1999), chromogranin- (Reinecke et al., 1991), polypeptide $Y Y$ - and neuropeptide $Y$-immunoreactive cells (El-Salhy et al., 1987) have been found, and new types of endocrine cells have been reported in the pancreas of the various vertebrates. In particular, the appearance of IR cells of unknown content (called X-cells) in the pancreas of the European common frog were also demonstrated (Etayo et al., 2000).

With the increasing demand for diabetic animal models and/or the usefulness of irradiation in many fields, the regional distribution and relative frequency of pancreatic endocrine cells, especially insulin- and glucagon-producing cells in laboratory animals, has attracted great attention in recent years (Warbritton et al., 1994; Gomez-Dumm et al., 1995; Fu et al., 1996). Many researchers have suggested that the species-dependent characteristic distribution of cells producing different hormones in the pancreas of each species of animal might be due to feeding habits, a concept that is now generally accepted (Wieczorek et al., 1998).

It was also reported that different regional distributions and relative frequencies of endocrine cells in the pancreatic islets existed in different portions of the pancreas, even in the pancreas of the same animal (Yukawa et al., 1999).

Despite biological, physiological and anatomical differences between the red-bellied frog, Bombina orientalis, and other anuran species, reports have seldom dealt with the endocrine cells in the pancreatic islets of this species. There is only one report on the distributions and relative frequencies of endocrine cells in the alimentary tract of the redbellied frog (Ku et al., 2000). And, with the exception of the European common frog (Etayo et al., 2000), quantitative studies of the anuran pancreas are scarce.

The object of this study was to determine the regional distribution and quantitative frequency of endocrine cells in the pancreas of the red-bellied frog by immunohistochemistry using antisera specific for insulin, glucagon, somatostatin, PP or secretin.

\section{Materials and Methods}

The red-bellied frog, Bombina orientalis, belonging to the order Anura is widely distributed in Korea. Ten adult specimens were captured in
Kyungsan, Korea, and used in this study without distinction for gender. The animals were phletomized under ethylether and samples from the pancreas were fixed in Bouin's solution. After paraffin embedding, 3-4 $\mu \mathrm{m}$ serial sections were prepared. Representative sections of each tissue were stained with hematoxylin and eosin for light microscopic examination of the normal pancreatic architecture.

The deparaffinised, and rehydrated sections were treated with methanol containing $0.3 \% \mathrm{H}_{2} \mathrm{O}_{2}$ for 30 min to block any endogenous peroxidase. Subsequently, the sections were incubated for $1 \mathrm{hr}$ at room temperature in normal goat serum (1:100), then stained immunohistochemically to identify specific endocrine cells using the peroxidase anti-peroxidase (PAP) method (Sternberger, 1979). In the first layer, the sections were incubated with antisera specific for individual pancreatic hormones for 12 hrs at $4^{\circ} \mathrm{C}$. Details of specific antisera used as the first layer are listed in Table 1. After rinsing in $0.01 \mathrm{M}$ phosphate buffered saline (PBS, pH 7.4, containing $0.05 \%$ Tween), anti-rabbit Ig $G$ serum raised in goats was used as the second layer at 1:200 dilution for $1 \mathrm{hr}$ at room temperature. They were then washed with PBS and the PAP complex was used as the third layer at 1:400 dilution for $1 \mathrm{hr}$ at room temperature. The peroxidase reaction was carried out in a solution 3,3'-diaminobenzidine tetrahydrochloride containing $0.01 \% \quad \mathrm{H}_{2} \mathrm{O}_{2}$ in $0.05 \mathrm{M}$ Tris- $\mathrm{HCl}$ buffer, $\mathrm{pH}$ 7.6. After immunostaining, the sections were lightly counterstained with Mayer's hematoxylin and the immunoreactive cells were observed under light microscope.

The specificity of each immunohistochemical reaction was determined as described by Sternberger (1979), including the replacement of specific antiserum by the same antiserum which had been

Table 1. Antisera used in this study.

\begin{tabular}{llll}
\hline \hline Antisera raised* & Code & Source & Dilution \\
\hline Insulin & 842613 & Diasorin, Stillwater, USA & $1: 2000$ \\
Glucagon & $8240-0004$ & Biogenesis, Kingston, USA & $1: 800$ \\
Somatostatin & PU0421295 & BioGenex Lab., San Ramon, USA & $1: 20$ \\
PP1 & PU0660495 & BioGenex Lab., San Ramon, USA & $1: 20$ \\
Secretin & $4660-0089$ & Biogenesis, Kingston, USA & $1: 320$ \\
\hline *All antisera were raised in rabbits except for insulin, which was raised in guinea pigs.
\end{tabular}

*All antisera were raised in rabbits except for insulin, which was raised in guinea pigs. 1) PP: bovine pancreatic polypeptide 
Table 2. Quantitative frequencies of specific immunoreactive endocrine cell populations in the pancreas of the red-bellied frog, Bombina orientalis.

\begin{tabular}{lcc} 
Immunoreactive cell & $\begin{array}{c}\text { No.of immunoreactive } \\
\text { cells/1000 cells* }\end{array}$ & $\begin{array}{c}\text { Percentage of immunoreactive cells } \\
\text { against each antiserum* }\end{array}$ \\
\hline Insulin & $65.40 \pm 14.56$ & $37.20 \pm 6.84$ \\
Glucagon & $32.70 \pm 7.32$ & $21.90 \pm 5.55$ \\
Somatostatin & $19.40 \pm 6.52$ & $11.60 \pm 4.33$ \\
PP 1) & $14.70 \pm 4.92$ & $8.60 \pm 2.72$ \\
Secretin & $39.60 \pm 10.36$ & $23.40 \pm 4.45$
\end{tabular}

* Ouantitative frequencies were calculated using an automated image analysis process (Soft Image System, Germany) coupled with light microscopy; 1) PP: pancreatic polypeptide.

preincubated with its corresponding antigen. The frequency of immunoreactive cells was calculated as the mean \pm standard deviation (S.D.) of 10 parts $(n=10)$ of pancreatic parenchyma. Among 1000 cells, including exocrine and endocrine cells, cells showing immunoreactivities against each antiserum were counted using an automated image analysis process (Soft Image System, Germany) coupled to light microscopy. In addition, the percentage of cells immunoreactive to each antiserum was determined among 100 cells of the total IR cell population.

\section{Results}

In this study, five types of immunoreactive endocrine cells were detected and quantified with antisera to insulin, glucagon, somatostatin, PP and secretin in the pancreas of the red-bellied frog. The frequency of these immunoreactive cell types in the pancreas is shown in Table 2.

Spherical-to-spindle or occasionally oval-toround-shaped immunoreactive cells were present in the pancreas. These were distributed throughout the pancreatic parenchyma between exocrine acinar cells, and were also observed as islet-like clusters.

\section{Insulin IR cells}

These cells were present in the pancreas as single cells or clusters. The single cells were dispersed throughout the pancreatic parenchyma, between exocrine acinar cells (Figure la). The clustered cells had the appearance of mammalian islet-like structures and were situated in the central regions (Figure $1 \mathrm{a}-\mathrm{c}$ ). The clusters of insulin IR cells were more numerous than the single-cells. The insulin IR cells showed a density of $65.40 \pm 14.56 / 1000$ cells and amounted to $37.20 \pm 6.84 \%$ of the total IR cell population (Table 2). This is the most predominant endocrine cell type in the pancreas of the red-bellied frog.

\section{Glucagon IR cells}

These cells were detected as single cells or clusters in the pancreas. The single cells were randomly distributed throughout the pancreatic parenchyma, between exocrine acinar cells (Figure $2 \mathrm{a}$ ). The clustered cells showed two distributional patterns. One showed a central core distributional pattern (Figure $2 \mathrm{~b}$ ) and the other showed a marginal distributional pattern (Figure 2c) like that of mammalian pancreatic islets. The glucagon IR cells showed a frequency of $32.70 \pm 7.32 / 1000$ cells and approximately $21.90 \pm 5.55 \%$ of immunoreactive cells was immunoreactive for glucagon (Table 2). This is the third most abundant endocrine cell type in the pancreas of this frog species.

\section{Somatostatin IR cells}

These immunoreactive cells were dispersed in the pancreatic parenchyma as single cells, three to four cells, or clusters. The single or three to four cells were randomly distributed throughout the pancreatic parenchyma between exocrine acinar cells. The clustered cells were localized exclusively in the marginal regions (Figure $3 \mathrm{a}-\mathrm{c}$ ). The somatostatin IR cells showed a frequency of $19.40 \pm 6.52 / 1000$ cells and approximately $11.60 \pm 4.33 \%$ of the immunoreactive cells was immunoreactive for somatostatin (Table 2). This is the fourth most abundant endocrine cell type in the pancreas of the red-bellied frog.

\section{PP IR cells}

These cells were randomly dispersed throughout the pancreatic parenchyma as single cells between exocrine acinar cells (Figure $4 a, b$ ). The PP IR cells showed a frequency of $14.70 \pm 4.92 / 1000$ cells and approximately $8.60 \pm 2.72 \%$ of the immunoreactive cell population was immunoreactive for PP (Table 2 ). This is the least abundant endocrine cell type in the pancreas of the red-bellied frog.

\section{Secretin IR cells}

These cells were dispersed in the pancreatic parenchyma as single cells and/or clusters, between 

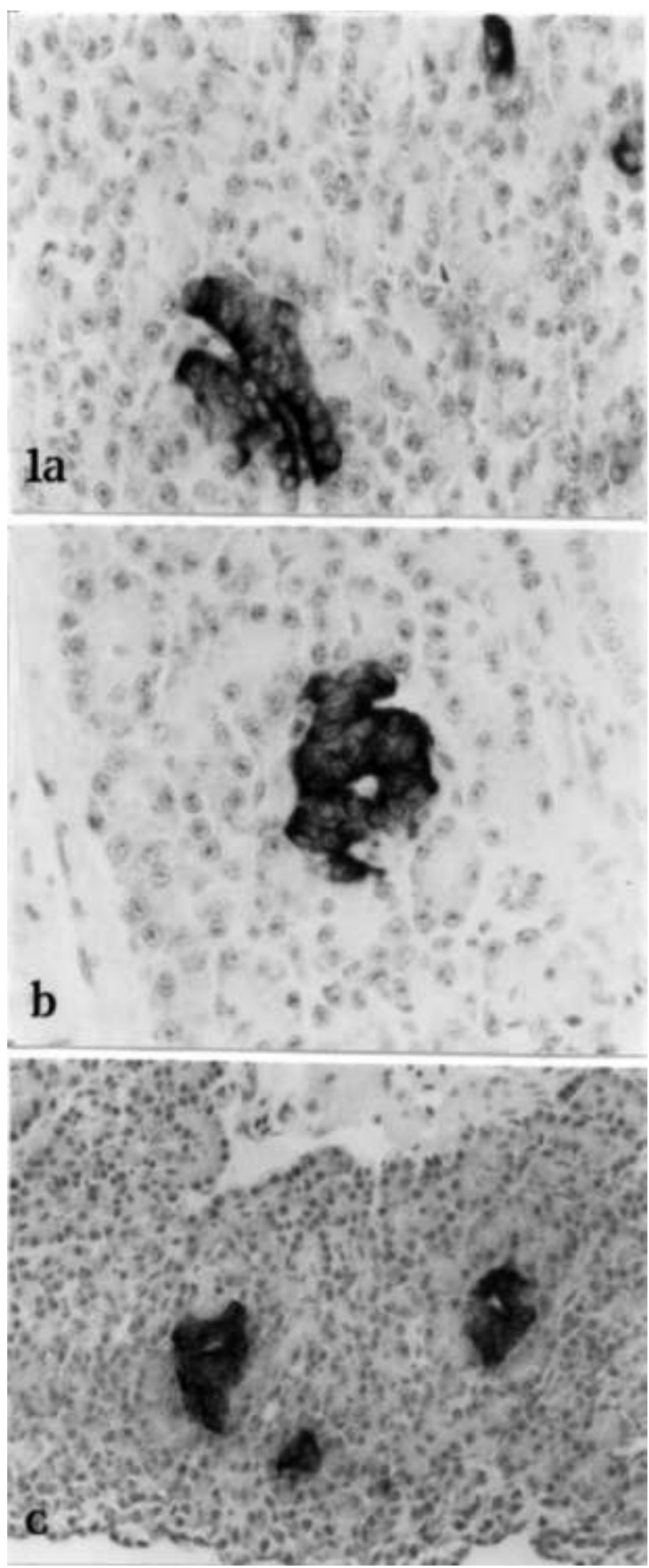

Figure 1. Insulin IR cells are distributed as single cells (a) and/or clusters (a-c) in the pancreas of the red-bellied frog. a, b. $\times 350$; c. $\times 175$; PAP method.
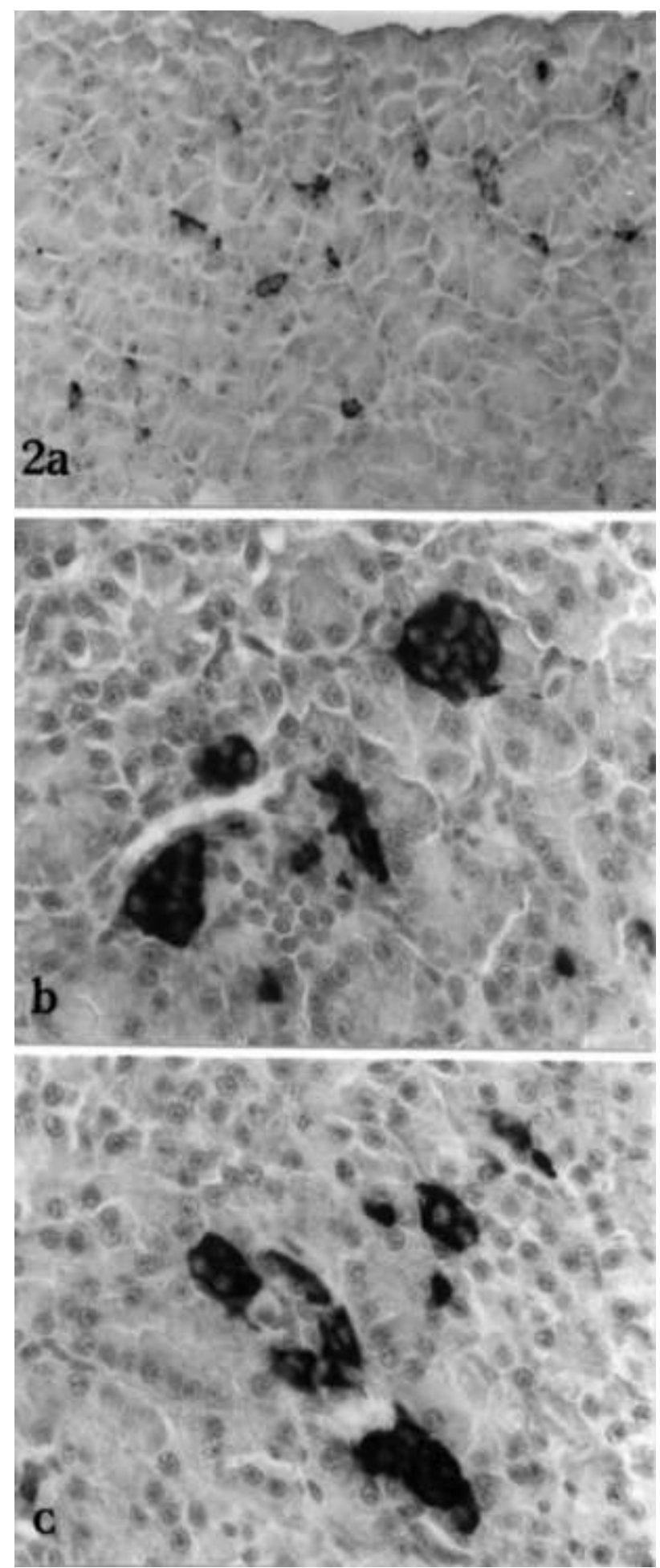

Figure 2. Glucagon IR cells are distributed as single cells (a) and/or clusters $(b, c)$ in the pancreas of the red-bellied frog. Clusters are distributed as a central core type (b) and a marginally distributed types (c). a. $\times 175 ;$ b, c. $\times 350$; PAP method. 


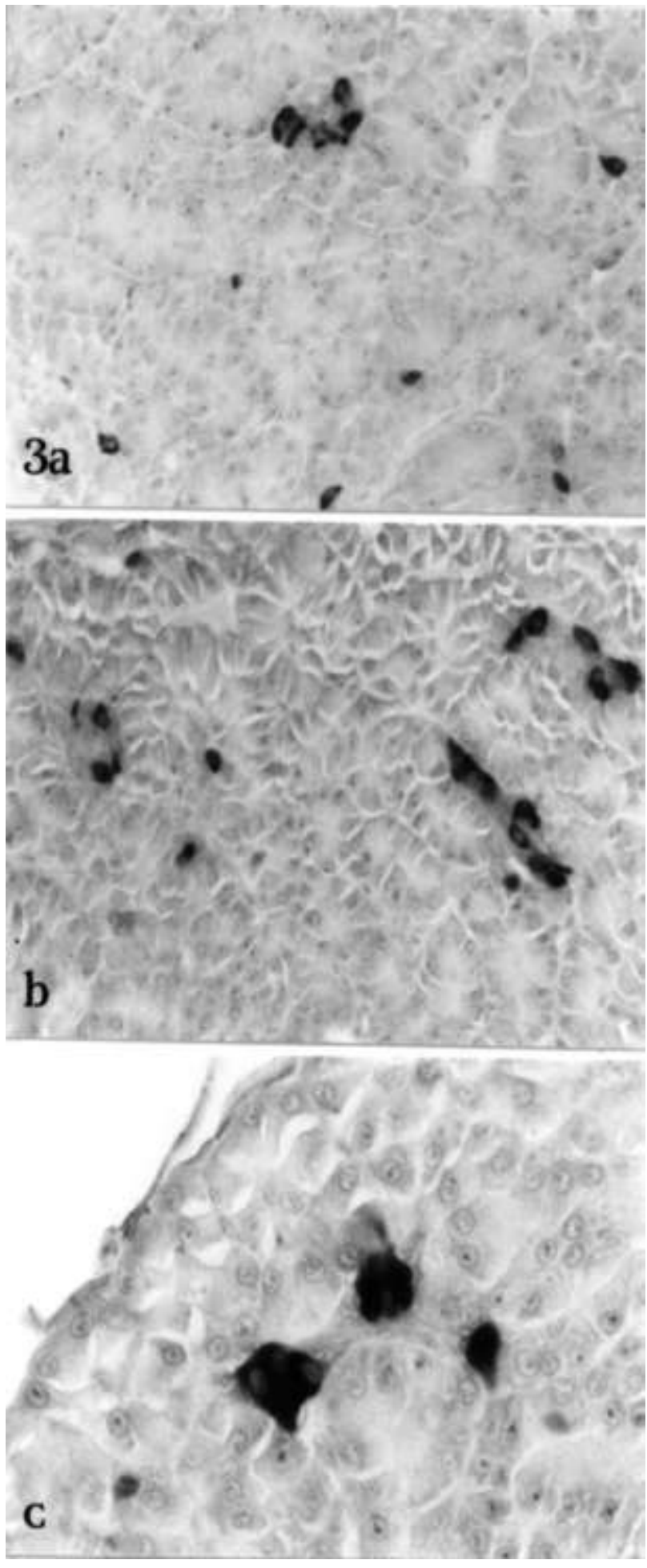

Figure 3. Somatostatin IR cells are distributed as single, three to four cells and/or clusters in the pancreas of the red-bellied frog (a-c). In the case of clusters, they are exclusively situated in the marginal regions $(b, c) . a, b . \times 175 ; c . \times 350$; PAP method.
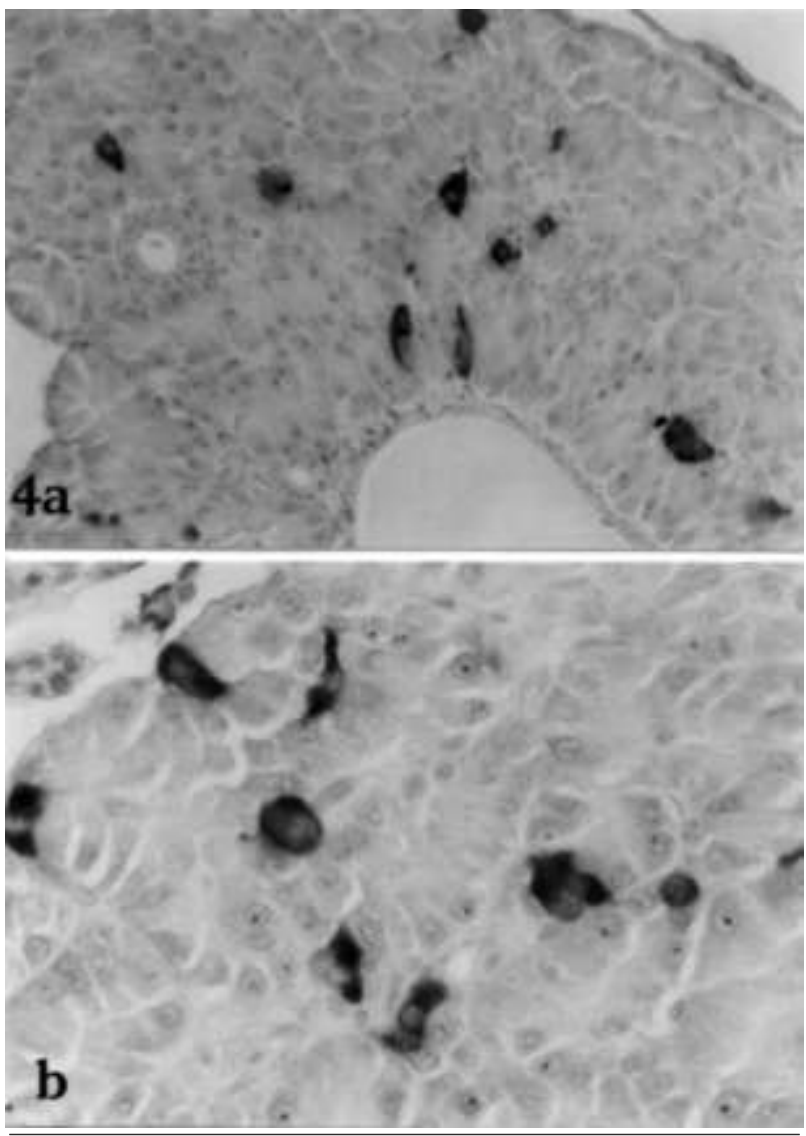

Figure 4. PP IR cells are distributed as single cells in the pancreas of the red-bellied frog $(a, b)$. a. $\times 175 ;$ b. $\times 350$; PAP method.

exocrine acinar cells. The single secretin IR cells were randomly distributed throughout the whole pancreatic parenchyma (Figure $5 \mathrm{a}, \mathrm{d}$ ). The clustered cells formed round- to spherical shaped-cores (Figure $5 b, c)$. The secretin IR cells showed a fre-

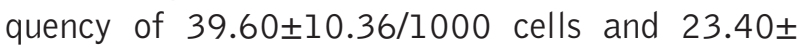
$4.45 \%$ of the immunoreactive cell population was immunoreactive for secretin (Table 2), making it the second most predominant endocrine cell type in the pancreas of the red-bellied frog.

\section{Discussion}

In the pancreas of the red-bellied frog, Bombina orientalis (Anura, Amphibian), all of the five endocrine cell types studied were distributed throughout the pancreatic parenchyma, between exocrine acinar cells; with the exception of the PP cells, they were also observed as islet-like clusters.

Insulin is synthesized in the $B$ cells of the pancreatic islets and regulates the serum glucose levels 

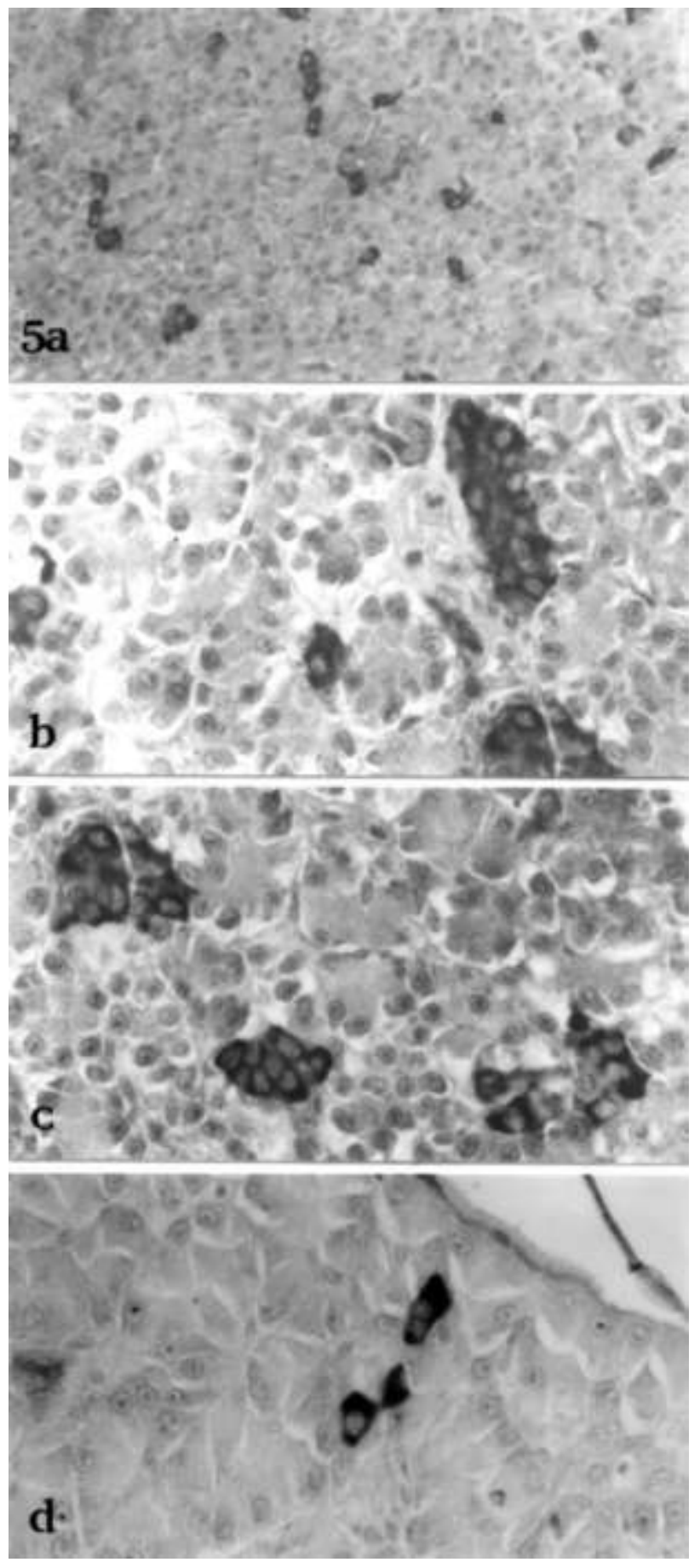

Figure 5. Secretin IR cells are distributed as single cells $(a, d)$ and/or clusters $(b, c)$ in the pancreas of the red-bellied frog. In the case of clusters, they form round to spherical shaped cores (b, c). a. $\times 87$; b-d. $\times 350$; PAP method.

(see Hsu and Crump, 1989). The regional distribution and relative frequency of insulin-immunoreactive cells in the pancreas were reported in the European common frog (Rana temporaria) (Ortiz de Zarate et al., 1991; Etayo et al., 2000) and
African clawed toad (Xenopus laevis) (Cowan et al., 1991; Maake et al., 1998; Lozano et al., 1999) among anuran amphibians. From these reports, it is well recognized that insulin IR cells are present throughout the anuran pancreas either in small clusters of single cells or as islet-like structures. Our results in the present study concurred with those of the above studies in that the insulin IR cells were found to be localized in the pancreas of the red-bellied frog as single cells or clusters. In the case of clusters, they presented a mammalian isletlike appearance and were situated in the central regions. Although reports dealing with the abundance of endocrine cells in the anuran pancreas are very few, insulin IR cells were the most predominant type in the pancreas of the red-bellied frog, showing a frequency of $65.40 \pm 14.56 / 1000$ cells, with $37.20 \pm 6.84 \%$ of all immunoreactive cells being immunoreactive for insulin. These results are similar to those of the European common frog (Etayo et al., 2000).

Glucagon is synthesized in the a cells of the pancreas and regulates glucose levels in blood (see Hsu and Crump, 1989). Morphologically similar cells are also observed in the digestive tract of the dog (Wieczorek et al., 1998). In the present study, glucagons IR cells were found as single cells or clusters in the pancreas of the red-bellied frog, similar to the insulin IR cells. However, two distributional patterns were detected in the case of clusters - central core and marginal distributional patterns. Although somewhat different distributional patterns were detected in the anuran pancreas with lobes, cells immunoreactive to glucagon were isolated as singles cells, clusters (central core) or in the margins of the islet-like structures quite similar to the results of the present study (Cowan et al., 1991; Lozano et al., 1999; Etayo et al., 2000). In addition, glucagons IR cells showed the third highest abundance in the present study, 32.70 $\pm 7.32 / 1000$ cells and $21.90 \pm 5.55 \%$ of all immunoreactive cels was immunoreactive for glucagon. These results are similar to those of European common frog (Etayo et al., 2000).

Somatostatin, which consists of 14 amino acids, was first isolated from the hypothalamus of sheep. The molecule mayu exist in the linear form and the cyclic form (Brazeau et al., 1973). This substance inhibits the secretion of gastrin, cholecystokinin, secretin, glucagon, insulin, motilin and gastric acid (Kitamura et al., 1984) and the absorption of 
amino acids, glucose and fatty acids in the gastrointestinal tract (Polak et al., 1976). In the pancreas of anurans, somatostatin IR cells were detected in the European common frog (Etayo et al., 2000), the African clawed toad (Shapiro et al., 1979; Hacker et al., 1983; Cowan et al., 1999; Lozano et al., 1999), and the green frog (Trandaburu et al., 1995). They were present as single cells or clusters in the pancreas of these species, including, in the present study, the red-bellied frog. In the case of cluster, they occupied marginal regions (Etayo et al., 2000). Cells immunoreactive to somatostatin showed the fourth highest frequency in the present study, $19.40 \pm 6.52 / 1000$ cells and approximately $11.60 \pm 4.33 \%$ of the immunoreactive cell population was immunoreactive for somatostatin. These results were quite similar to those of the European common frog (Etayo et al., 2000) and the African clawed toad (Hacker et al., 1983).

$P P$, a peptide hormone containing 36 amino acids, is synthesized by $F$ cells in the pancreatic islets (see Hsu and Crump, 1989). The specific function of this peptide is not clear, but inhibition of food intake has been postulated as a possible function (Hsu and Crump, 1989). In addition, some researchers reported that $\mathrm{PP}$ promotes the secretion of gastric acid and stimulates glycolysis in the liver in avian species (Polak et al., 1976). The appearance of PP IR cells was fairly well identified in various species of anuran amphibians, and it has been shown that they are conspicuously distributed in the pancreas as single cells, or in peripheral regions as islet-like cell clusters (McKay et al., 1998; Maake et al., 1998; Lozano et al., 1999; Etayo et al., 2000). However, in the present study, they were randomly dispersed in the pancreatic parenchyma only as single cells, between exocrine acinar cells. These differences are considered to be species-dependent characteristics. PP IR cells showed the lowest frequency, 14.70 $\pm 4.92 / 1000$ cells in this study, and $8.60 \pm 2.72 \%$ of the immunoreactive cell population was immunoreactive for PP. These results are similar to those of European common frog (Etayo et al., 2000).

Secretin stimulates fluid secretion of the pancreas (Suzuki et al., 2001). In all vertebrates so far investigated, except for some species of rodents, secretin IR cells have proved to be exclusive to the small intestine, usually with a preference for the duodenum (Solcia et al., 1989; Kitamura et al., 1990; Ku et al., 2002). Until now, there have been no reports dealing with the presence of secretin IR cells in the pancreas, except for the human fetus (Vincze et al., 2001), in which a transient appearance of such cells was demonstrated in 18- and 20week old fetuses (Vincze et al., 2001). However, in the present study, numerous secretin IR cells were detected in the pancreas of the red-bellied frog as single cells and/or clusters, between exocrine acinar cells. This is thus the first report describing the appearance of such cells in the adult pancreas of vertebrates. In addition, the secretin IR cells were found to be the second most predominant endocrine

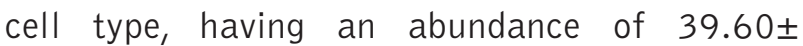
$10.36 / 1,000$ cells and consisting of approximately $23.40 \pm 4.45 \%$ of the immunoreactive cell population.

In conclusion, distributional patterns of immunoreactive cells in the pancreas of the red-bellied frog were quite similar to those of other anuran species but the appearance of secretin IR cells in the pancreas of this species is unique.

\section{References}

Alli-Rachedi A, Varndell IM, Adrian TE, Gapp DA, Van Noorden S, Bloom SR, et al. Peptide YY (PYY) immunoreactivity is co-stored with glucagon-related immunoreactants in endocrine cells of the gut and pancreas. Histochemistry 1984;80:487-91.

Brazeau $P$, Vale $W$, Burgurs $R$, Ling $N$, Butcher $M$, Rivier $J$, et al. Hypothalamic polypeptide that inhibits the secretion of immunoreactive pituitary growth hormone. Science 1973;179:77-9.

Cowan BJ, Foty RA, Liversage RA. Insulin, glucagon and somatostatin localization in the pancreas of metamorphosed Xenopus laevis. Tissue Cell 1991;23:777-87.

D'Este L, Buffa R, Pelagi M, Siccardi AG, Renda T. Immunohistochemical localization of chromogranin $A$ and $B$ in the endocrine cells of the alimentary tract of the green frog, Rana esculenta. Cell Tissue Res 1994;277:341-9.

El-Salhy M, Grimelius L, Emson PC, Falkmer S. Polypeptide YY- and neuropeptide $Y$-immunoreactive cells and nerves in the endocrine and exocrine pancreas of some vertebrates: an onto- and phylogenetic study. Histochem J 1987;19:111-7.

El-Salhy M, Grimelius L, Wilander E, Abu-Sinna G, Lundqvist G. Histological and immunohistochemical studies of the endocrine cells of the gastrointestinal mucosa of the toad (Bufo regularis). Histochemistry 1981;71:53-65.

Etayo JC, Montuenga LM, Sesma P, Diaz de Rada 0, Rovira J, Villaro AC. Characterization of pancreatic endocrine cells of the European common frog, Rana temporaria. Gen Comp Endocrinol 2000;117: 366-80.

Foty RA, Lai-Fook JE, Liversage RA. Localization of insulin, glucagon and somatostatin in the pancreas of the adult newt, Notophthalmus viridescens. Tissue Cell 1989;21:1-10.

Fu Q, Honda M, Ohgawara H, Igarashi N, Toyada C, Omori $Y$, et al. Morphological analysis of pancreatic endocrine cells in newborn animals delivered by experimental diabetic rats. Diabetes Res Clin Pract 1996;31:57-62.

Gomez-Dumm CL, Console GM, Lunna GC, Dardenne M, Goya RG. Quantitative immunohistochemical changes in the endocrine pancreas of nonobese diabetic (NOD) mice. Pancreas 1995;11:396401.

Hacker G, Pohlhammer K, Breitfuss A, Adam H. Somatostatin-immunoreactive cells in the gastro-entero-pancreatic endocrine system of Xenopus laevis. Z Mikrosk Anat Forsch 1983;97:929-40. 
Hsu WH, Crump MH. The endocrine pancreas. In: Veterinary endocrinology and reproduction. McDonald LE and Pineda M H, Eds. Lea \& Febige: Philadelphia; 1989. p. 186-201.

Ito $\mathrm{H}$, Hashimoto $\mathrm{Y}$, Kitagawa $\mathrm{H}$, Kon $\mathrm{Y}$, Kudo N. Distribution of chromogranin containing cells in the porcine gastroenteropancreatic endocrine system. Jpn J Vet Sci 1987;50:395-404.

Jansson $L$, Sandler S. The influence of cyclosporin $A$ on the vascular permeability of the pancreatic islets and on diabetes induced by multiple low dose of streptozotocin in the mouse. Virchows Archiv A Pathol Anat Histopathol 1988;412:225-30.

Kitamura N, Yamada J, Calingasan NY, Yamashita T. Immunocytochemical distribution of endocrine cells in the gastrointestinal tract of the horse. Equine Vet J 1984;16:103-7.

Kitamura N, Yamada J, Watanabe T, Yamashita T. An immunohistochemical study on the distribution of endocrine cells in the gastrointestinal tract of the musk shrew, Suncus murinus. Histol Histopathol 1990;5:83-8.

Kobayashi K, Syed-Ali S. Cell types of the endocrine pancreas in the shark, Scylliorhinus stellaris as revealed by correlative light and electron microscopy. Cell Tissue Res 1981;215:475-90.

Ku SK, Lee HS, Lee JH. An immunohistochemical study of endocrine cells in the alimentary tract of the red-bellied frog, Bombina orientalis. J Vet Med Sci 2000;62:589-94.

Ku SK, Lee JH, Lee HS, Park KD. The regional distribution and relative frequency of gastrointestinal endocrine cells in SKH-1 hairless mice: an immunohistochemical study. Anat Histol Embryol 2002; 31:78-84.

Lopez J, Cuesta N, Cuttitta F, Martinez A. Adrenomedullin in nonmammalian vertebrate pancreas: an immunocytochemical study. Gen Comp Endocrinol 1999;115:309-22.

Lozano MT, Hernandez MP, Agulleiro B. Endocrine pancreatic cells from Xenopus laevis: light and electron microscopic studies. Gen Comp Endocrinol 1999;114:191-205.

Maake C, Hanke W, Reinecke M. An immunohistochemical and morphometric analysis of insulin, insulin-like growth factor I, glucagon, somatostatin, and PP in the development of the gastro-entero-pancreatic system of Xenopus laevis. Gen Comp Endocrinol 1998; 110:182-95.

McKay DM, Shaw C, Thim L, Johnston CF, Halton DW, Fairweather L, et al. The complete primary structure of pancreatic polypeptide from the European common frog, Rana temporaria. Regul Pept 1990; 31:187-97.

Nakajima T, Sasuhara T, Tshikawa 0. New frog skin peptides homologous to the ranatensin or bombesin family. In: Gut peptides, secretion, function and clinical aspects. Miyoshi A, Ed. Elsevier/North Holland: Amsterdam; 1979. p. 14-8.

Oikawa T, Ogawa K, Taniguchi K. Immunocytochemical studies on the pancreatic endocrine cells in the Japanese newt (Cynopus pyrrhogaster). Jikken Dobutsu 1992;41:505-14.

Orci L. Macro- and micro-domains in the endocrine pancreas. Diabetes 1982;31:538-64.

Ortiz de Zarate A, Villaro AC, Etayo JC, Diaz de Rada 0, Montuenga LM, Sesma P, et al. Development of the endocrine pancreas during larval phases of Rana temporaria. An immunocytochemical and ultrastructural study. Cell Tissue Res 1991;264:139-50.
Polak JM, Adrian TE, Bryant MG, Bloom SR, Heitz PH, Pearse AGE. Pancreatic polypeptide in the insulomas, gastrinomas and glucagonomas. Lancet 1976;1:328-30.

Reinecke M, Hoog A, Ostenson CG, Efendic S, Grimelius L, Falkmer S. Phylogenetic aspects of pancreastatin- and chromogranin-like immunoreactive cells in the gastro-entero-pancreatic neuroendocrine system of vertebrates. Gen Comp Endocrinol 1991;83:16782.

Rindi G, Buffa R, Sessa F, Tortora 0, Solcia E. Chromogranin A, B and $C$ immunoreactivities of mammalian endocrine cells: distribution from costored hormones/prohormones and relationship with argyrophil component of secretory granules. Histochemistry 1986;85: 19-28.

Shapiro B, Sheppard M, Kronheim S, Pimstone BL. Tissue distribution of immunoreactive somatostatin in the South African clawed toad (Xenopus laevis). J Endocrinol 1979;80:407-8.

Solcia E, Usellini L, Buffa R, Rindi G, Villani L, Aguzzi A, et al. Endocrine cells producing regulatory peptides. In: Regulatory peptides. Polak J M, Ed. Birkhäuser: Basel; 1989. p. 220-46.

Sternberger LA. The unlabeled antibody peroxidase-antiperoxidase (PAP) method. In: Immunocytochemistry. Sternberger LA, Ed. John Wiley \& Sons: New York; 1979. p. 104-69.

Sternberger LA, Hardy PH, Cuculis JJ, Meyer HG. The unlabeled antibody enzyme method of immunocytochemistry: preparation and properties of soluble antigen-antibody complex (Horseradish peroxidase-antihorseradish peroxidase) and use in identification of spirochetes. J Histochem Cytochem 1970;18:315-33.

Suzuki A, Naruse S, Kitagawa M, Ishiguro H, Yoshikawa T, Ko SB, et al. 5-hydroxytryptamine strongly inhibits fluid secretion in guinea pig pancreatic duct cells. J Clin Invest 2001;108:749-56.

Trandaburu T, Nurnberger F, Ali SS. Distribution and ultrastructure of somatostatin-immunoreactive cells in the pancreas of Rana esculenta. Anat Anz 1995;177:213-9.

Van Noorden S, Polak JM. Hormones of the alimentary tract. In: Hormones and evolution. Barrington EJW, Ed. Academic Press: New York; 1979. p. 791-828.

Vincze E, Kantor 0, Kausz M, Nemeth J, Arimura A, Gonda P, et al. Comparative study on the appearance of various bioactive peptides in foregut derivates during the ontogenesis. J Physiol Paris 2001; 95:99-103.

Warbritton A, Gill AM, Yen TT, Bucci T, Wolff GL. Pancreatic islet cells in preobese yellow Avy/- mice: relation to adult hyperinsulinemia and obesity. Proc Soc Exp Biol Med 1994;206:145-51.

Wieczorek G, Pospischil A, Perentes EA. Comparative immunohistochemical study of pancreatic islets in laboratory animals (rats, dogs, minipigs, nonhuman primates). Exp Toxicol Pathol 1998;50:15172.

Yamada J, Campos VJM, Kitamura N, Pacheco AC, Yamashita T, Yanaihara N. An immunohistochemical study of endocrine cells in the pancreas of Caiman latirostris (Alligatorinae), with special reference to pancreatic motilin cells. Biomed Res 1986;7:199-208.

Yukawa M, Takeuchi T, Watanabe T, Kitamura S. Proportions of various endocrine cells in the pancreatic islets of wood mice (Apodemus speciosus). Anat Histol Embryol 1999;28:13-6. 